\title{
PET Brain Imaging of Neuropeptide Y2 Receptors Using $N$-11C-Methyl-JNJ-31020028 in Pigs
}

\author{
Michael Winterdahl ${ }^{1}$, Hélène Audrain ${ }^{1}$, Anne M. Landau ${ }^{1,2}$, Donald F. Smith ${ }^{3}$, Pascal Bonaventure ${ }^{4}$, James R. Shoblock ${ }^{4}$, \\ Nicholas Carruthers ${ }^{4}$, Devin Swanson ${ }^{4}$, and Dirk Bender ${ }^{1}$ \\ ${ }^{1}$ Department of Nuclear Medicine and PET Center, Aarhus University Hospital, Aarhus, Denmark; ${ }^{2}$ Center of Functionally \\ Integrative Neuroscience (CFIN), Aarhus University, Aarhus, Denmark; ${ }^{3}$ Translational Neuropsychiatry Unit, Psychiatric Hospital \\ of Aarhus University, Risskov, Denmark; and ${ }^{4}$ Janssen Research and Development, LLC, San Diego, California
}

Neuropeptide Y2 (NPY2) receptors are implicated in diverse brain disorders, but no suitable PET radiotracers are currently available for studying NPY2 receptors in the living brain. We developed a novel positron-emitting radioligand based on the NPY2 receptor antagonist JNJ-31020028 (N-(4-(4-[2-(diethylamino)-2-oxo-1-phenylethyl] piperazin-1-yl)-3-fluorophenyl)-2-pyridin-3-ylbenzamide) and used the radiotracer for PET brain imaging in pigs. Methods: In vitro receptor autoradiography studies were performed to establish the anatomic distribution of NPY2 receptors in the pig brain. In vivo, baseline 90-min PET recordings of $\mathrm{N}$ - ${ }^{11} \mathrm{C}$-methyl-JNJ-31020028 were conducted in anesthetized Yorkshire $\mathrm{x}$ Landrace pigs, concurrent with arterial blood sampling. Postchallenge scans were conducted after injection of unlabeled JNJ-31020028 as a pharmacologic intervention. Cyclosporine A was used to enhance levels of the PET radiotracer in the brain. The PET images were manually coregistered to a MR imaging atlas of the pig brain. Maps of the $\mathrm{N}-{ }^{11} \mathrm{C}$-methylJNJ-31020028 volume of distribution in the brain were prepared, and regional binding potentials of NPY2 receptors toward the radioligand were calculated using the simplified reference tissue method. Results: In autoradiography studies, $N$ - ${ }^{11} \mathrm{C}$-methyl-JNJ-31020028 receptor binding sites were observed primarily in the hippocampus and were inhibited by unlabeled JNJ-31020028. In PET studies, $\mathrm{N}-{ }^{11} \mathrm{C}$-methyl-JNJ-31020028 was metabolized slowly in the bloodstream, with $25 \%$ of the ${ }^{11} \mathrm{C}$-labeled parent compound remaining $30 \mathrm{~min}$ after injection. PET imaging showed baseline binding potentials of $0.64 \pm 0.07$ in the thalamus, $0.55 \pm 0.02$ in the caudate, and $0.49 \pm 0.03$ in the hippocampus. Graphical reference region analyses demonstrated that $N-{ }^{11} \mathrm{C}$-methyl-JNJ-31020028 binding was reversible; infusion of unlabeled JNJ-31020028 markedly displaced the PET radioligand from binding sites in the hippocampus, thalamus, caudate nucleus, and cerebellum but not in the corpus callosum, which served as reference region for nonspecific binding. Conclusion: $N-{ }^{11} \mathrm{C}$-methyl-JNJ-31020028 has several suitable properties for PET neuroimaging of NPY2 receptors. First, it is metabolized slowly in the bloodstream of pigs. Second, using cyclosporine, the target-tobackground ratio of $\mathrm{N}^{-11} \mathrm{C}$-methyl-JNJ-31020028 is sufficient for estimating pharmacokinetic parameters. Third, $\mathrm{N}-{ }^{11} \mathrm{C}$-methyl-JNJ31020028 binds reversibly and competitively to cerebral sites known to contain relatively high numbers of NPY2 receptors, such as the hippocampus, thalamus, caudate nucleus, and cerebellum. Fourth, white matter such as corpus callosum, known to contain

Received Apr. 24, 2013; revision accepted Dec. 6, 2013.

For correspondence or reprints contact: Michael Winterdahl, Department of Nuclear Medicine and PET Center, Aarhus University Hospital, Noerrebrogade 44, Aarhus, Denmark 8000C.

E-mail: mw@pet.auh.dk.

Published online Mar. 10, 2014.

COPYRIGHT (c) 2014 by the Society of Nuclear Medicine and Molecular Imaging, Inc. negligible numbers of NPY2 receptors, can serve as a reference region for estimating binding potentials in brain regions. To our knowledge, there is no other radioligand with these favorable properties and with this specificity for NPY2 receptors, which makes $\mathrm{N}-{ }^{11} \mathrm{C}$-methyl-JNJ-31020028 the first candidate radioligand for PET investigations of NPY2 receptors in the living brain.

Key Words: neuropeptide Y; receptors; N-methyl-JNJ-31020028; PET; receptor binding

J Nucl Med 2014; 55:635-639

DOI: 10.2967/jnumed.113.125351

$\mathbf{N}$ europeptide Y (NPY) exerts its functions via a family of Gprotein-coupled receptor subtypes (1-3). Of particular interest are the NPY type 2 (NPY2) receptors, found primarily in corticolimbic regions, with particular high densities in the hippocampus of several species including human (4). NPY2 receptors are located primarily presynaptically, where they control the release of endogenous NPY (5). Studies performed in laboratory animals indicate that low release of NPY in the hypothalamus is linked with increased food intake and obesity (6-8), so a suitable PET radioligand may provide links between central NPY2 receptor dysfunctions and human obesity. With regard to neurologic disease, NPY dysfunction is implicated in Parkinson disease, in that postmortem studies of human brain tissue showed increased levels of NPY messenger RNA in the nucleus accumbens, caudate nucleus, and putamen of Parkinsonian patients, compared with neurologically healthy subjects $(9,10)$. NPY2 receptors have also been implicated in depressive disorders and adverse emotional reactions to stressful life events (2). Thus, interest in a suitable PET radiotracer for studying NPY2 receptors in the living human brain relates to unanswered questions regarding causal neuromolecular mechanisms in brain disorders.

Recently, reports appeared on a selective, high-affinity, low-molecular -weight NPY2 receptor antagonist, JNJ-31020028 ( $N$-(4-(4-[2(diethylamino)-2-oxo-1-phenylethyl]piperazin-1-yl)-3-fluorophenyl)2-pyridin-3-ylbenzamide) (11,12). After subcutaneous administration in rats, JNJ-31020028 occupied Y2 receptor binding sites as revealed by ex vivo receptor autoradiography (13). On the basis of these initial findings, we selected this compound as a potential PET candidate. Challenges in the synthesis of ${ }^{11} \mathrm{C}$-labeled JNJ-31020028 caused us to focus attention on its $\mathrm{N}^{11} \mathrm{C}$-methyl analog (Fig. 1). The autoradiographic studies reported here show $N-{ }^{11} \mathrm{C}$-methyl-JNJ-31020028 to be suitable for identifying NPY2 receptors in the pig brain. Subsequent PET studies reported here on $N-{ }^{11} \mathrm{C}$-methyl-JNJ-31020028 


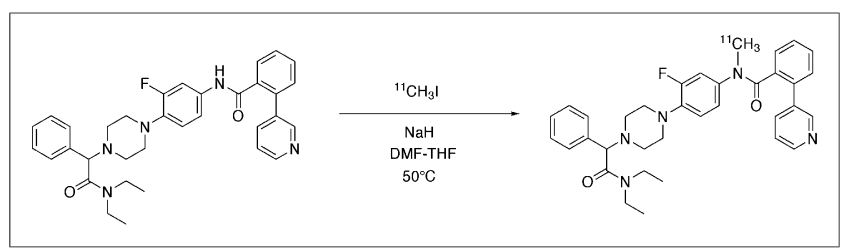

FIGURE 1. Radiosynthesis of $\mathrm{N}^{-11} \mathrm{C}$-methyl-JNJ-31020028 from JNJ31020028.

provide the first images, to our knowledge, of NPY2 receptors in the living brain.

\section{MATERIALS AND METHODS}

Full details of the materials and methods are provided in the supplemental data (available at http://jnm.snmjournals.org).

\section{Radiochemistry}

We used JNJ-31020028 ( $N$-(4-(4-[2-(diethylamino)-2-oxo-1-phenylethyl] piperazin-1-yl)-3-fluorophenyl)-2-pyridin-3-ylbenzamide) (14) and $\mathrm{N}$ methylated-JNJ-31020028 (12), kindly provided by Janssen Research and Development. We performed ${ }^{11} \mathrm{C}$ labeling by a semiautomated system. ${ }^{11} \mathrm{C}$-methyl iodide was trapped in a solution of JNJ-31020028 and $\mathrm{NaH}$ dissolved in $\mathrm{N}, \mathrm{N}$-dimethylformamide and tetrahydrofuran. After heating, $1 \mathrm{~mL}$ of the high-performance liquid chromatography (HPLC) mobile phase was added to the reaction vessel. The crude product was then purified by preparative HPLC. The fraction containing $\mathrm{N}-{ }^{11} \mathrm{C}$-methyl-JNJ-31020028 was eluted from the column and collected in water. Analytic HPLC was run to determine the radiochemical purity and the product identity by coinjection of a cold reference compound.

\section{Animals}

Experiments using animals were performed in accordance with the Danish Animal Experimentation Act and the European convention for the protection of vertebrate animals used for experimental and other scientific purposes (ETS no. 123). We used 6 female, 3- to 4-mo-old, prepubertal pigs weighing $35-42 \mathrm{~kg}$.

\section{Autoradiographic Imaging}

Tissue Preparation. The procedures for autoradiography were adapted from methods described by Bonaventure et al. (13). Brains were obtained from 2 pigs anesthetized with ketamine and midazolam and euthanized by intravenous injection of sodium pentobarbital. The brains were rapidly removed, frozen, and stored at $-80^{\circ} \mathrm{C}$. Sagittal sections were cut and thaw-mounted on chrom-alun gelatin double-size microscope slides.

${ }^{125}$ I-Peptide $Y Y(P Y Y)$ Competitive Binding. Incubations were performed at room temperature for $50 \mathrm{pM}{ }^{125} \mathrm{I}-\mathrm{PYY}$ (PerkinElmer Inc.) in the presence or absence of JNJ-31020028 at concentrations between $10^{-10}$ and $10^{-4} \mathrm{M}$. After incubation, the slides were washed in ice-cold buffer, dipped in ice-cold deionized water, and dried overnight. Slides and tissue-calibrated autoradiographic standards for ${ }^{125} \mathrm{I}$ were apposed to sensitive radiographic imaging plates for $24 \mathrm{~h}$. Digitized computer images were visualized and quantified using ImageGauge software (version 4.0; Fujifilm).

$\mathrm{N}^{-11} \mathrm{C}$-methyl-JNJ-31020028 Competitive Binding. Sections were incubated with $\mathrm{N}^{11} \mathrm{C}$-methyl-JNJ-31020028 in the presence or absence of JNJ-3102002. After incubation, the slides were washed in ice-cold buffer and dipped in ice-cold deionized water. Slides were dried and analyzed as described above.

\section{PET Imaging}

Four Yorkshire $x$ Landrace pigs (weight, 35-40 kg) underwent PET imaging. On arrival to the PET Center, pigs were anesthetized by intra- muscular injection of midazolam, followed by intubation and isoflurane anesthesia $(15,16)$. Catheters were inserted in the urinary bladder, femoral vein, and femoral artery. The pigs were placed in the scanner, with head and body immobilized by surgical tape. A whole-body PET recording of the distribution of $\mathrm{N}^{11} \mathrm{C}$-methyl-JNJ-31020028 was performed for 1 pig after a single intravenous injection of $\mathrm{N}-{ }^{11}$ C-methyl-JNJ-31020028. Organs with relatively high accumulation of tracer relative to their surroundings were identified by visual inspection.

PET Brain Imaging. $N-{ }^{11} \mathrm{C}-$ methyl-JNJ-31020028 was administered intravenously during the initial $15 \mathrm{~s}$ of a 90 -min scan. Three pigs were used to determine whether cyclosporine A (17) enhanced the signal obtained in the brain after intravenous injection of $\mathrm{N}^{11} \mathrm{C}$-methyl-JNJ31020028 , and one other pig was used to determine whether binding of $\mathrm{N}-{ }^{11} \mathrm{C}$-methyl-JNJ-31020028 in the brain after cyclosporine-pretreatment was displaceable by unlabeled JNJ-31020028. We euthanized the anesthetized pigs with an intravenous overdose of pentobarbital on completion of PET scanning. During the dynamic $\mathrm{N}^{-11} \mathrm{C}$-methyl-JNJ-31020028 PET scan, a series of blood samples was collected from a femoral artery. Concentrations of radioactivity were corrected for radioactive decay. The fraction of untransformed $\mathrm{N}^{11} \mathrm{C}$-methyl-JNJ-31020028 was measured by radio-HPLC in extracts of plasma. PET images were processed using Montreal Neurologic Institute MINC software (18). We used the simplified reference tissue model (19) to estimate regional binding potentials $\left(\mathrm{BP}_{\mathrm{ND}}\right)$ and to derive parametric images.

\section{Statistics}

The half maximal inhibitory concentration values in autoradiographic studies were estimated using GraphPad Prism software (version 4.0; GraphPad Software Inc.). Other statistical analyses were performed using SigmaPlot (version 11.0; Systat Software Inc.). We used a paired-samples $t$ test to determine whether cyclosporine A enhanced the signal obtained in brain after intravenous injection of $\mathrm{N}^{11} \mathrm{C}$-methyl-JNJ-31020028. Multivariate ANOVA with Bonferroni adjustment was used to determine whether $\mathrm{BP}_{\mathrm{ND}}$ values of $N-{ }^{11} \mathrm{C}$-methyl-JNJ-31020028 differed significantly between brain regions.

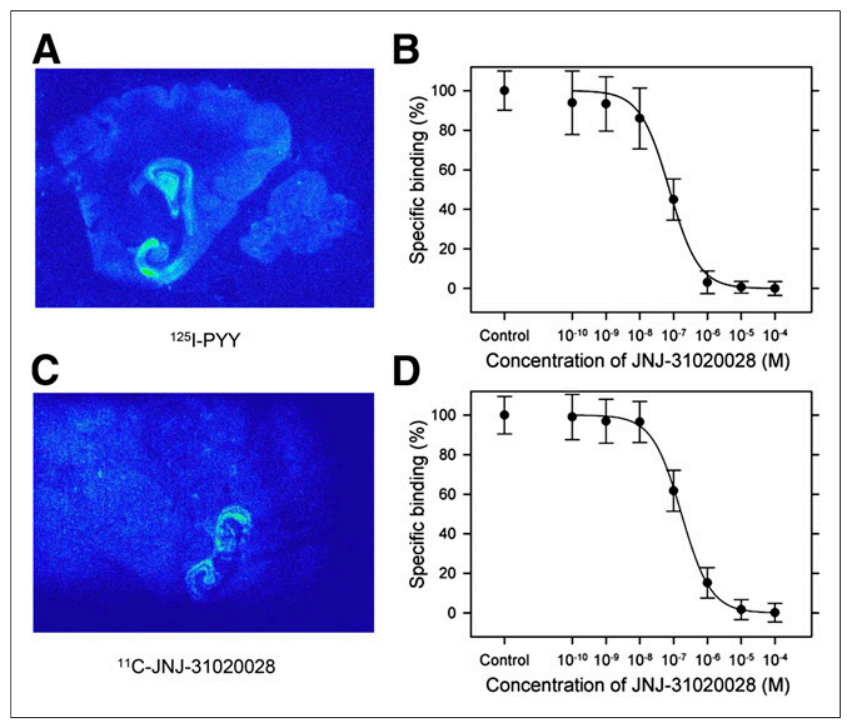

FIGURE 2. (A and C) Digitized computer images of distribution of 125 PYY (A) and $N-{ }^{11} \mathrm{C}$-methyl-JNJ-31020028 (C) binding sites in 20- $\mu \mathrm{m}$ sagittal cryosections of pig brain. Anterior part of brain has been removed so that sections could fit on double-sized microscope slides. (B and D) Inhibition plots of ${ }^{125}$ I-PYY (B) or $\mathrm{N}^{-11} \mathrm{C}$-methyl-JNJ-31020028 (D) binding in presence of $\mathrm{JNJ}-31020028$. 


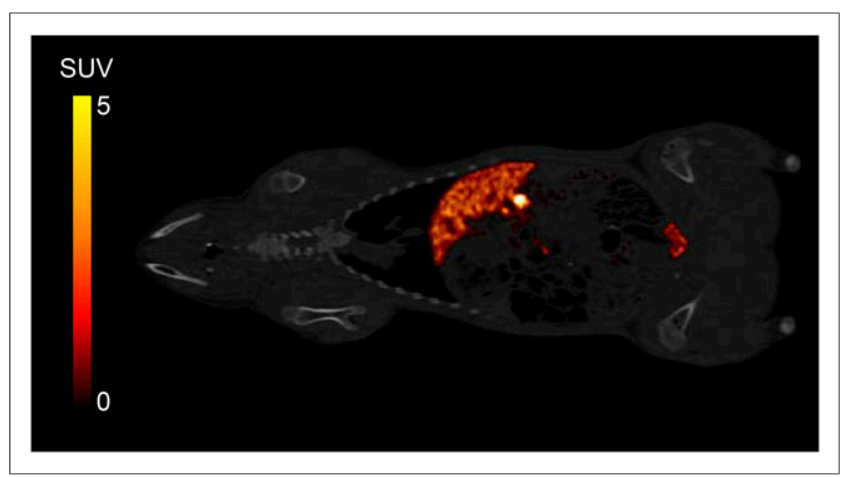

FIGURE 3. Whole-body distribution of $\mathrm{N}^{-11} \mathrm{C}$-methyl-JNJ-31020028 in pig. Standardized uptake value (SUV) image is overlaid on anatomic CT image. SUV is defined as percentage radioactivity relative to injected dose divided by body weight.

\section{RESULTS}

\section{Autoradiographic Imaging}

Figure $2 \mathrm{~A}$ shows the anatomic distribution and binding properties of receptors sensitive to ${ }^{125} \mathrm{I}-\mathrm{PYY}$, in the presence of the selective NPY1 receptor antagonist N2-(diphenylacetyl)- $N$-[(4-hydroxyphenyl)methyl]-D-arginine amide (BIBP) 3226 or unlabeled JNJ31020028 in the pig brain. The highest densities of ${ }^{125}$ I-PYY receptor binding sites were observed in the hippocampus, $5.1 \pm 0.2$ $\mathrm{fmol} / \mathrm{mg}$, especially the hilus fascia dentatae, $7.8 \pm 0.2 \mathrm{fmol} / \mathrm{mg}$. Lower densities were observed in regions of the cerebral cortex and cerebellum, $2.7 \pm 0.2$ and $3.0 \pm 0.2 \mathrm{fmol} / \mathrm{mg}$, respectively. JNJ-31020028 $\left(10^{-4} \mathrm{M}\right)$ inhibited ${ }^{125}$ I-PYY labeling in the hippocampus and cerebellum. Nonspecific binding of ${ }^{125} \mathrm{I}-\mathrm{PYY}$, determined on adjacent sections in the presence of $1 \mu \mathrm{M}$ NPY, was below 10\%. BIBP-3226 (1 mM) almost completely inhibited the labeling of ${ }^{125} \mathrm{I}-\mathrm{PYY}$ in the cerebral cortical regions. As determined by quantitative autoradiography in the pig hippocampus (Fig. 2B), JNJ-31020028 competed for ${ }^{125}$ I-PYY binding sites with high affinity (hilus fascia dentatae; the logarithm of the half maximal effective concentration $\left.\left[\log \mathrm{EC}_{50}\right]\right),-7.13$; $95 \%$ confidence interval, -7.50 to -6.76$)$.

Figure $2 \mathrm{C}$ illustrates receptor sensitivity to $\left.\mathrm{N}^{11} \mathrm{C}\right]$-methyl-JNJ31020028. The anatomic distribution of $\mathrm{N}^{1}{ }^{11} \mathrm{C}$-methyl-JNJ-31020028 is restricted to the hippocampus, compared with the relatively widespread distribution of ${ }^{125} \mathrm{I}-\mathrm{PYY}$ binding sites. JNJ-31020028 competed with $N-{ }^{11}$ C-methyl-JNJ-31020028 at binding sites (Fig. 2D) with approximately equal affinity (hilus fascia dentatae; $\log \mathrm{EC}_{50}$, $-6.8 ; 95 \%$ confidence interval, -6.3 to -7.3 ).

\section{PET Imaging}

Whole-Body Recordings. Figure 3 shows a whole-body image of $\mathrm{N}^{11} \mathrm{C}$-methyl-JNJ-31020028 in a pig. The highest levels of radioactivity are seen in the liver, gallbladder, and urinary bladder, despite continuous drainage of the bladder during the PET scan.

In Vivo Blood Chemistry and Metabolite Determination. $\mathrm{N}^{11} \mathrm{C}-$ methyl-JNJ-31020028 was metabolized relatively slowly in the bloodstream, with $25 \%$ of ${ }^{11} \mathrm{C}$-derived radioactivity as parent compound $30 \mathrm{~min}$ after injection (Fig. 4). Two major metabolites were identified using radio-HPLC. Both metabolites eluted before the parent compound, indicating higher polarity of the metabolites than the parent compound. Cyclosporine and JNJ-31020028 challenge failed to affect the metabolism of $\mathrm{N}^{11} \mathrm{C}$-methyl-JNJ-31020028.
Cyclosporine. Figure 5A shows representative time-radioactivity curves measured in the corpus callosum and hippocampus during the 90 min after injection of $N_{-}{ }^{11} \mathrm{C}$-methyl-JNJ-31020028, with and without cyclosporine-pretreatment. Radioactivity derived from $\mathrm{N}-{ }^{11} \mathrm{C}$ methyl-JNJ-31020028 reached peak levels in the brain within $5 \mathrm{~min}$ of injection. Cyclosporine significantly increased the amount of $\mathrm{N}-{ }^{11} \mathrm{C}$-methyl-JNJ-31020028 in the brain, consistent with inhibition of P-glycoprotein (P-gp) at the blood-brain barrier (20).

PET N- ${ }^{11}$ C-Methyl-JNJ-31020028 BP ${ }_{N D}$ and Competitive Binding. Figure $5 \mathrm{~B}$ presents representative time-radioactivity curves measured in the corpus callosum and hippocampus during the $90 \mathrm{~min}$ after injection of $\mathrm{N}^{11} \mathrm{C}$-methyl-JNJ-31020028 in a baseline condition and after an intravenous bolus infusion of JNJ-31020028 (2 mg/kg). Time-radioactivity curves of the corpus callosum failed to differ between baseline and challenge conditions. Therefore, we selected the corpus callosum as the reference tissue for the estimation of the $\mathrm{BP}_{\mathrm{ND}}$ of $\mathrm{N}^{-11} \mathrm{C}$-methyl-JNJ-31020028 in other regions. Table 1 presents kinetic parameters of $N-{ }^{11} \mathrm{C}$-methyl-JNJ-31020028 under baseline conditions and during the unlabeled JNJ-31020028 challenge. JNJ-31020028 challenge markedly reduced the apparent binding of the radiotracer in the hippocampus, thalamus, caudate nucleus, and cerebellum, indicating readily reversible binding. Figure 6 shows a parametric map of the average $\mathrm{BP}_{\mathrm{ND}}$ of $N-{ }^{11} \mathrm{C}$ methyl-JNJ-31020028 in the living pig brain.

\section{DISCUSSION}

The novel positron-emitting radiotracer described here, $\mathrm{N}^{11} \mathrm{C}$ methyl-JNJ-31020028, has now been assessed by autoradiography in brain sections and by in vivo PET in the pig brain. Because radiolabeling approaches to obtain authentic radiolabeled JNJ31020028 have not yet been successful, we decided to investigate whether radioactive $N-{ }^{11} \mathrm{C}$-methyl-JNJ-31020028 could also be used for PET studies of NPY2 receptors. Our radiographic findings show the highest densities of $\mathrm{N}^{11} \mathrm{C}$-methyl-JNJ-31020028 binding in the hippocampus and cerebellum, in agreement with the anatomic distribution of NPY2 receptors in other animal species $(4,13,21)$, despite relatively low receptor densities when compared with other receptor types. Furthermore, our autoradiography studies confirm

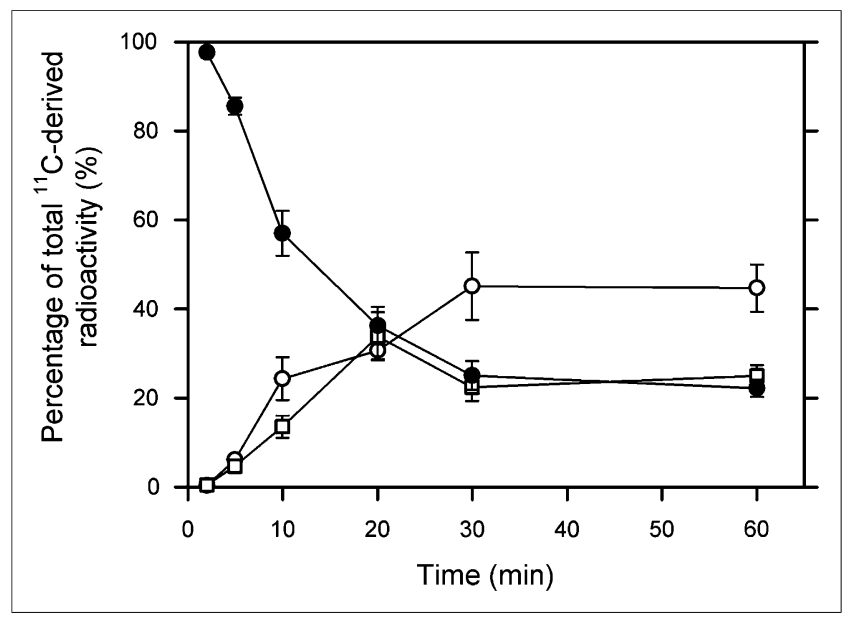

FIGURE 4. Metabolism of $N-{ }^{11} \mathrm{C}$-methyl-JNJ-31020028 measured in blood plasma of pigs after intravenous injection. Symbols are as follows: $N$ - $\left[{ }^{11} \mathrm{C}\right]$ methyl-JNJ-31020028 (๑), first-eluting metabolite $(\mathrm{O})$, second-eluting metabolite $(\square)$. 

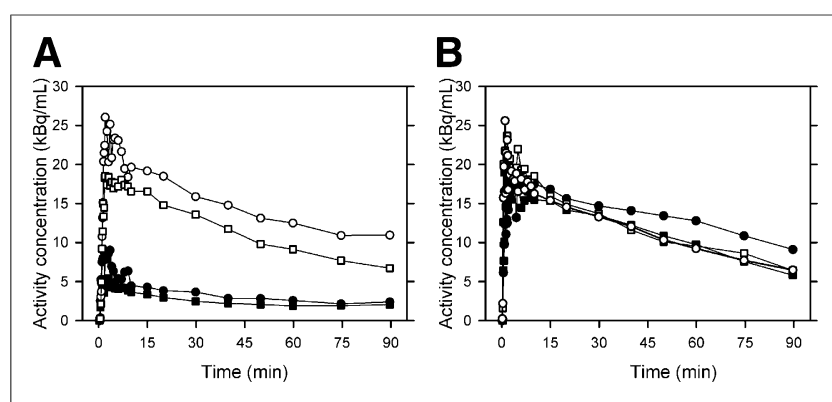

FIGURE 5. Time course of radioactivity concentration studied by PET in living pig brain after intravenous injection of $\mathrm{N}-{ }^{11} \mathrm{C}$-methyl-JNJ31020028. (A) Measurements in corpus callosum ( $\mathbf{E}$ ) and hippocampus $(\bullet)$ without administration of cyclosporine, and corpus callosum ( $\square$ ) and hippocampus $(O)$ with administration of cyclosporine. (B) Measurements in corpus callosum ( $)$ and hippocampus ( $\bullet$ in baseline condition and corpus callosum $(\square)$ and hippocampus $(O)$ after challenge with JNJ-31020028.

that the corpus callosum is almost devoid of Y2 receptors in the pig, as previously described in rats and humans $(4,22)$, thus making this structure an appropriate candidate as input for reference tissue models (19).

PET studies performed in the absence of cyclosporine gave a value of less than unity for the ratio between the area under the wholebrain time-activity curve and the plasma time-activity curve of $N-{ }^{11}$ C-methyl-JNJ-31020028, suggesting an efflux transport process of $\mathrm{N}^{11} \mathrm{C}$-methyl-JNJ-31020028 at the blood-brain barrier. We attribute this efflux transport process to P-gp, and we interpret the marked increase in the brain distribution of $N-{ }^{11} \mathrm{C}$-methyl-JNJ31020028 radioactivity as inhibition of $\mathrm{P}$-gp by cyclosporine. The magnitude of this inhibition was similar for all regions of the brain, indicating that P-gp activity is uniform throughout the pig brain. Thus, dynamic PET imaging suggests that $N-{ }^{11} \mathrm{C}$-methyl-JNJ-31020028 diffuses readily across the blood-brain barrier and that inhibition of the P-gp transporter improves the target-to-background ratio of $N-{ }^{11} \mathrm{C}$-methyl-JNJ-31020028, allowing for better estimates of pharmacokinetic parameters. The inhibition of P-gp by cyclosporine could have resulted in an increase in $\mathrm{N}^{11} \mathrm{C}$-methyl-JNJ-31020028 distribution into tissues that express P-gp, mainly the intestinal epithelium, hepatocytes, and renal proximal tubular cells (23), lowering the area under the plasma time-activity curve of $N-{ }^{11} \mathrm{C}$ methyl-JNJ-31020028 in the presence of cyclosporine. However, the area under the plasma time-activity curves of $\mathrm{N}^{-11} \mathrm{C}$-methylJNJ-31020028 in the presence of cyclosporine was not significantly lower than that in the absence of cyclosporine. Thus, we conclude that cyclosporine did not affect the distribution of $N-{ }^{11} \mathrm{C}$ methyl-JNJ-31020028.

$N-{ }^{11} \mathrm{C}$-methyl-JNJ-31020028 distributed rapidly into the brain, with a delay between the peak of the brain time-activity curve and the blood curve of approximately $5 \mathrm{~min}$. Brain kinetic profiles of $N-{ }^{11} \mathrm{C}$-methyl-JNJ-31020028 showed pseudoequilibrium with plasma $N-{ }^{11} \mathrm{C}$-methyl-JNJ-31020028 in less than $4 \mathrm{~min}$. We chose the corpus callosum as reference tissue for estimating pharmacokinetic parameters because the distribution of our PET radiotracer in that region was unaffected by inhibitory challenge. In addition, partialvolume effects and movement artifacts can be limited by use of such a relatively large, well-defined structure as the reference region for estimating $\mathrm{BP}_{\mathrm{ND}}$ by the simplified reference tissue model. For clinical studies, the use of the corpus callosum as a reference
TABLE 1

Magnitude of $\mathrm{BP}_{\mathrm{ND}}$ of $\mathrm{N}-{ }^{11} \mathrm{C}$-methyl-JNJ-31020028 in Living Brain of 1 Anesthetized Prepubertal Pig

\begin{tabular}{lcc}
\hline \multicolumn{1}{c}{ Region } & Baseline & $\begin{array}{c}\text { Methyl-JNJ- } \\
\text { 31020028 challenge }\end{array}$ \\
\hline Medial thalamus & $0.64 \pm 0.07$ & $0.22 \pm 0.01$ \\
Vermis & $0.61 \pm 0.05$ & $0.12 \pm 0.01$ \\
\hline Lateral thalamus & $0.60 \pm 0.11$ & $0.22 \pm 0.02$ \\
\hline Caudate & $0.55 \pm 0.02$ & $0.13 \pm 0.01$ \\
Putamen & $0.52 \pm 0.05$ & $0.18 \pm 0.02$ \\
\hline Mesencephalon & $0.50 \pm 0.07$ & $0.08 \pm 0.15$ \\
Hippocampus & $0.49 \pm 0.03$ & $0.04 \pm 0.01$ \\
Globus pallidus & $0.48 \pm 0.06$ & $0.10 \pm 0.08$ \\
Diencepalon & $0.47 \pm 0.08$ & $0.07 \pm 0.01$ \\
\hline Cerebellum* & $0.36 \pm 0.06$ & $0.08 \pm 0.01$ \\
\hline Frontal cortex & $0.24 \pm 0.07$ & $0.10 \pm 0.03$ \\
Frontal white matter & $0.22 \pm 0.05$ & $0.11 \pm 0.02$ \\
Pons & $0.19 \pm 0.18$ & $0.04 \pm 0.00$ \\
\hline Medulla oblongata & $0.14 \pm 0.07$ & $0.18 \pm 0.02$ \\
\hline
\end{tabular}

*Vermis excluded.

tissue for data analysis of $N-{ }^{11} \mathrm{C}$-methyl-JNJ-31020028 binding by simplified reference tissue model may obviate the need for arterial cannulation.

Some shortcomings of our study deserve attention. First, the design of our autoradiographic study did not allow the determination of the receptor affinity of $N-{ }^{11} \mathrm{C}$-methyl-JNJ-31020028 by homologous competition, because the nonlabeled methyl-JNJ-31020028 was not available for these investigations. Second, we focused only on the hippocampus for autoradiography, whereas studies on other regions would have been of interest for comparison with subsequent PET images. Third, the design of our whole-body imaging was limited, providing only a preliminary estimate $(0.009 \mathrm{mSv} / \mathrm{GBq})$ of the effective human dose that would be expected to be produced by an intravenous injection of $\mathrm{N}^{11} \mathrm{C}$-methyl-JNJ-31020028. Clearly, whole-body dosimetry studies of $\mathrm{N}^{1}{ }^{11} \mathrm{C}$-methyl-JNJ-31020028 in humans are required before the PET radiotracer can be considered for imaging NPY2 receptors in the clinic. Fourth, studies will be needed to determine whether cyclosporine is required to inhibit the efflux of $\mathrm{N}^{1}{ }^{11} \mathrm{C}$-methyl-JNJ-31020028 from the brain in awake humans $(20,24,25)$ in the same manner as it was performed in the present study in anesthetized pigs.

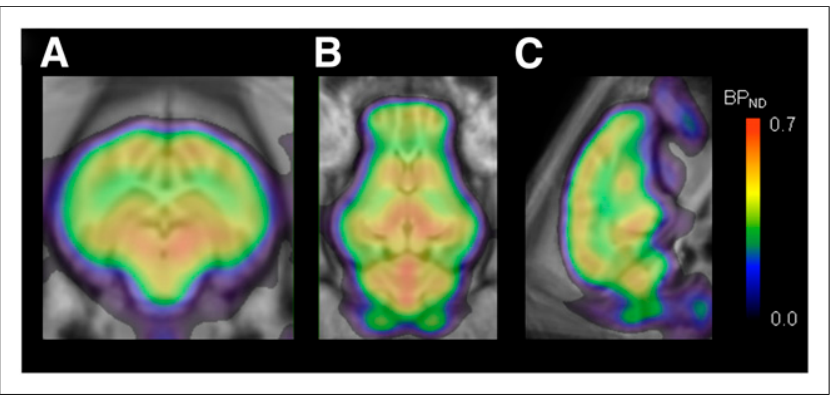

FIGURE 6. Parametric images of $N$ - ${ }^{11} \mathrm{C}$-methyl-JNJ-31020028 $\mathrm{BP}_{\mathrm{ND}}$ in living pig brain. Image is mean of 4 separate determinations, resampled into MR imaging-based common stereotactic space for pig brain and shown superimposed on MR imaging atlas. 


\section{CONCLUSION}

The present findings show that $N-{ }^{11} \mathrm{C}$-methyl-JNJ-31020028 has suitable properties as a PET radiotracer for determining the binding characteristics of NPY2 receptors in the living brain of anesthetized pigs. First, $N-{ }^{11} \mathrm{C}$-methyl-JNJ-31020028 is metabolized slowly in the bloodstream. Second, using cyclosporine, the target-

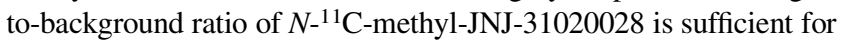
estimating pharmacokinetic parameters. Third, $\mathrm{N}^{1}{ }^{11} \mathrm{C}$-methyl-JNJ31020028 binds reversibly and competitively to cerebral sites such as the hippocampus, thalamus, caudate nucleus, and cerebellum. Fourth, white matter such as the corpus callosum can serve as the reference region for nonspecific binding. We view $N-{ }^{11} \mathrm{C}$-methylJNJ-31020028 as a novel lead compound toward a PET radiotracer for assessing NPY2 receptors in human brain disorders.

\section{DISCLOSURE}

The costs of publication of this article were defrayed in part by the payment of page charges. Therefore, and solely to indicate fact, this article is hereby marked "advertisement" in accordance with 18 USC section 1734. This work was supported by a research grant from Lundbeck. No other potential conflict of interest relevant to this article was reported.

\section{ACKNOWLEDGMENTS}

We thank Janssen Research and Development, LLC, San Diego, California, for providing generous supplies of compounds. We thank the staff of the Aarhus PET Center for their assistance with this research project.

\section{REFERENCES}

1. Michel MC, Beck-Sickinger A, Cox H, et al. XVI. International union of pharmacology recommendations for the nomenclature of neuropeptide Y, peptide YY, and pancreatic polypeptide receptors. Pharmacol Rev. 1998;50:143-150.

2. Heilig M. The NPY system in stress, anxiety and depression. Neuropeptides. 2004;38:213-224.

3. Melnick IV. Cell type-specific postsynaptic effects of neuropeptide Y in substantia gelatinosa neurons of the rat spinal cord. Synapse. 2012;66:640-649.

4. Dumont Y, Jacques D, Bouchard P, Quirion R. Species differences in the expression and distribution of the neuropeptide Y Y1, Y2, Y4, and Y5 receptors in rodents, guinea pig, and primates brains. J Comp Neurol. 1998;402:372-384.

5. King PJ, Widdowson PS, Doods HN, Williams G. Regulation of neuropeptide Y release by neuropeptide $\mathrm{Y}$ receptor ligands and calcium channel antagonists in hypothalamic slices. J Neurochem. 1999;73:641-646.

6. Kalra SP, Dube MG, Sahu A, et al. Neuropeptide Y secretion increases in the paraventricular nucleus in association with increased appetite for food. Proc Natl Acad Sci USA. 1991;88:10931-10935.
7. Stanley BG, Leibowitz SF, Neuropeptide Y. Stimulation of feeding and drinking by injection into the paraventricular nucleus. Life Sci. 1984;35:2635-2642.

8. Huang XF, Han M, Storlien LH. The level of NPY receptor mRNA expression in diet-induced obese and resistant mice. Brain Res Mol Brain Res. 2003;115:21-28.

9. Cannizzaro C, Tel BC, Rose S, et al. Increased neuropeptide Y mRNA expression in striatum in Parkinson's disease. Brain Res Mol Brain Res. 2003;110:169176.

10. Kerkerian L, Bosler O, Pelletier G, Nieoullon A. Striatal neuropeptide Y neurones are under the influence of the nigrostriatal dopaminergic pathway: immunohistochemical evidence. Neurosci Lett. 1986;66:106-112.

11. Shoblock JR, Welty N, Nepomuceno $D$, et al. In vitro and in vivo characterization of JNJ-31020028 (N-(4-\{4-[2-(diethylamino)-2-oxo-1-phenylethyl]piperazin-1-yl\}3-fluorophe nyl)-2-pyridin-3-ylbenzamide), a selective brain penetrant small molecule antagonist of the neuropeptide Y Y(2) receptor. Psychopharmacology (Berl). 2010;208:265-277.

12. Swanson DM, Wong VD, Jablonowski JA, et al. The discovery and synthesis of JNJ 31020028, a small molecule antagonist of the neuropeptide Y Y(2) receptor. Bioorg Med Chem Lett. 2011;21:5552-5556.

13. Bonaventure P, Nepomuceno D, Mazur C, et al. Characterization of N-(1-acetyl2,3-dihydro- ${ }^{1} \mathrm{H}$-indol-6-yl)-3-(3-cyano-phenyl)-N-[1-(2-cyclopen tyl-ethyl)-piperidin4yl]acrylamide (JNJ-5207787), a small molecule antagonist of the neuropeptide Y Y2 receptor. J Pharmacol Exp Ther. 2004;308:1130-1137.

14. Cippitelli A, Rezvani AH, Robinson JE, et al. The novel, selective, brain-penetrant neuropeptide Y Y2 receptor antagonist, JNJ-31020028, tested in animal models of alcohol consumption, relapse, and anxiety. Alcohol. 2011;45:567-576.

15. Winterdahl M, Keiding S, Sorensen M, et al. Tracer input for kinetic modelling of liver physiology determined without sampling portal venous blood in pigs. Eur $J$ Nucl Med Mol Imaging. 2011;38:263-270.

16. Alstrup AK, Smith DF. Anaesthesia for positron emission tomography scanning of animal brains. Lab Anim. 2013;47:12-18.

17. Liow JS, Lu S, McCarron JA, et al. Effect of a P-glycoprotein inhibitor, cyclosporine $\mathrm{A}$, on the disposition in rodent brain and blood of the 5-HT1A receptor radioligand, $\left[{ }^{11} \mathrm{C}\right](\mathrm{R})-(-)-\mathrm{RWAY}$. Synapse. 2007;61:96-105.

18. Watanabe H, Andersen F, Simonsen CZ, et al. MR-based statistical atlas of the Gottingen minipig brain. Neuroimage. 2001;14:1089-1096.

19. Lammertsma AA, Hume SP. Simplified reference tissue model for PET receptor studies. Neuroimage. 1996;4:153-158.

20. Eyal S, Ke B, Muzi M, et al. Regional P-glycoprotein activity and inhibition at the human blood-brain barrier as imaged by positron emission tomography. Clin Pharmacol Ther. 2010;87:579-585.

21. Diez M, Koistinaho J, Dearmond SJ, et al. Marked decrease of neuropeptide Y Y2 receptor binding sites in the hippocampus in murine prion disease. Proc Natl Acad Sci USA. 1997;94:13267-13272.

22. Widdowson PS. Quantitative receptor autoradiography demonstrates a differential distribution of neuropeptide-Y Y1 and Y2 receptor subtypes in human and rat brain. Brain Res. 1993;631:27-38.

23. Bansal T, Jaggi M, Khar RK, Talegaonkar S. Emerging significance of flavonoids as P-glycoprotein inhibitors in cancer chemotherapy. J Pharm Pharm Sci. 2009; 12:46-78.

24. Hsiao P, Bui T, Ho RJ, Unadkat JD. In vitro-to-in vivo prediction of P-glycoprotein-based drug interactions at the human and rodent blood-brain barrier. Drug Metab Dispos. 2008;36:481-484.

25. Kannan P, John C, Zoghbi SS, et al. Imaging the function of P-glycoprotein with radiotracers: pharmacokinetics and in vivo applications. Clin Pharmacol Ther. 2009;86:368-377. 